UDC 347.4

LBC 67.304.1

\title{
LIQUIDATED DAMAGES: THE ANALYSIS OF DEVELOPMENT OF THE DOMESTIC COURT PRACTICE
}

\author{
Alexander V. Syatchikhin \\ Perm State National Research University, Perm, Russian Federation
}

\begin{abstract}
Introduction: the article is devoted to the analysis of development of the Russian court practice of liquidated damages. The latter (damages) are one of the ways of contractual determination of the amount of damages, originally formed by the legal practice of the countries of Anglo-Saxon law, and subsequently accepted by the systems of civil law justice and is widely used in the international transactions. Thus, in these cases there is a strict distinction between liquidated damages and a penalty. Moreover, in the Anglo-Saxon countries, the latter, in the sense that the domestic legislation gives it, is recognized as an invalid contract term, because its recovery does not correspond to the recovery function of civil liability in the field of contract law. Methods: in the preparation of the article there were used both the general scientific and specific scientific methods of cognition, and there were used the techniques of formal logic. Results: the author identifies several stages of development of the court practice on reimbursement of liquidated damages, in the early stages associated with a penalty, and later correctly interpreted by the domestic law enforcement authority. Conclusions: in the domestic court practice the gradual formation of the legal position regarding the possibility of the contractual determination of the amount of damages can be traced. In the first stage, the terms of the contract are recognized as inconsistent with the law, in the second one liquidated damages are associated with a penalty, in the third one the law enforcement authority acknowledges their conformity to the public law, and formulates the criteria of validity of the conditions about the contractual determination of damages. The perception by the court practice of the foreign system sets the corresponding vector of development of the contractual liability, in particular, illustrates the strengthening of private law in this sphere.
\end{abstract}

Key words: liquidated damages, damages, contractual liability, civil liability, remedies.

УДК 347.4

ББК 67.304.1

\section{ВОЗМЕЩЕНИЕ ЗАРАНЕЕ ОЦЕНЕННЫХ УБЫТКОВ: АНАЛИЗ РАЗВИТИЯ ОТЕЧЕСТВЕННОЙ СУДЕБНОЙ ПРАКТИКИ}

\author{
Александр Валентинович Сятчихин \\ Пермский государственный национальный исследовательский университет, \\ г. Пермь, Российская Федерация
}

\begin{abstract}
Введение: статья посвящена анализу развития российской судебной практики разрешения споров, связанных со взысканием сумм заранее оцененных убытков. Последние составляют один из способов договорного определения размеров убытков, изначально сформированный правоприменительной практикой стран англосаксонского права, а впоследствии воспринятый правопорядками стран континентального права и и широко применяемый в международном обороте. При этом в указанных случаях происходит строгое ㄱ. разграничение заранее оцененных убытков и неустойки (штрафа). Более того, в странах англосаксонского ๓ं права последняя в том значении, которое ей придает отечественное законодательство, признается в качестве недействительного условия договора, поскольку ее взыскание не соответствует восстановительной функции гражданско-правовой ответственности в сфере договорного права. Методы: при подготовке материала статьи применялись как общенаучные, так и частнонаучные методы познания, а также использовались приемы формальной логики. Результаты: автор выделяет несколько стадий развития судебной практики по возмещению заранее оцененных убытков, на первых этапах отождествляемых с неустойкой, а впоследствии коррект-
\end{abstract}


но воспринятых отечественным правоприменителем. Выводы: в отечественной судебной практике прослеживается поэтапное формирование правовой позиции относительно возможности договорного определения размеров убытков. На первом этапе такие условия договора признаются противоречащими действующему законодательству, на втором - заранее оцененные убытки отождествляются с неустойкой, на третьем правоприменитель признает их соответствие публичному правопорядку, а также формулирует критерии действительности условий о договорном определении убытков. Восприятие судебной практикой зарубежной конструкции задает и соответствующий вектор развития договорной ответственности, в частности, иллюстрирует усиление в этой сфере частноправовых начал.

Ключевые слова: заранее оцененные убытки, возмещение убытков, договорная ответственность, гражданско-правовая ответственность, способы защиты прав.

\section{Введение}

Под заранее оцененными убытками (далее - ЗОУ) понимается установленная договором денежная сумма (порядок ее определения), представляющая разумную оценку предвидимых убытков, которую сторона обязуется уплатить в случае неисполнения или ненадлежащего исполнения условий договора.

В юридической литературе рассматриваемый феномен часто отождествляется со смежными гражданско-правовыми явлениями, а именно с неустойкой, компенсацией в авторском праве и институтом возмещения потерь (indemnity). При этом интересную закономерность показывают результаты анализа развития отечественной судебной практики по возмещению 3ОУ, поэтому с некоторой долей условности выделим три этапа ее развития.

\section{Первый этап: отождествление $30 У$ с договорной неустойкой}

Изначально российские суды воспринимали условия о договорных убытках не иначе как условия о неустойке (см., например, постановления ФАС Московского округа от 13 марта 2009 г. № КГ-А40/1319-09, Девятого арбитражного апелляционного суда от 22 декабря 2009 г. № 09АП-24142/2009-ГК). В этой связи верным представляется замечание М.П. Крашенинникова о подмене понятий: автор справедливо указывает, что «отсутствие детально разработанных механизмов взыскания убытков приводит к тому, что стороны, страхуясь, устанавливают достаточно большую договорную неустойку, рассчитывая на то, что в случае неисполнения обя- зательства полученная ими сумма неустойки покроет возникшие вследствие нарушения убытки. Данная практика представляется порочной, так как приводит к подмене понятий и искажению представлений о назначении института неустойки» [3, с. 10].

Кроме того, встречались и более радикальные решения. Так, ВАС РФ в Определении от 21 января 2011 г. № ВАС-18347/10 по делу № А19-1828/10-8, касающемуся возмещения 3ОУ, фактически отказал в защите добросовестному кредитору, поставив под сомнение значимость основополагающих принципов свободы договора, недопустимости произвольного вмешательства кого-либо в частные дела, обеспечения восстановления нарушенных прав, их судебной защиты и осуществления гражданских прав своей волей и в своем интересе, а также запрета на извлечение преимущества из недобросовестного поведения контрагента. Суд, рассматривая дело в порядке надзора, не нашел оснований для передачи дела в Президиум, обосновывая свое решение следующим:

Во-первых, 30У не были квалифицированы судами как неустойка: «Суды со ссылками на положения статей 330, 331 ГК РФ отказали в удовлетворении исковых требований, указав, что соглашением сторон не предусмотрено взыскание неустойки за нарушение обязательств в случае недовыборки угля».

Во-вторых, 3ОУ не были квалифицированы судами как убытки, так как первые «не являются санкцией, поскольку возможность их взыскания поставлена в зависимость от наличия убытков как таковых. Совокупность обстоятельств, необходимых для взыскания убытков, предусмотренная статьями 15, 393 ГК РФ, истцом не доказана». 


\section{Второй этап: признание $30 У$ соответствующими публичному порядку РФ}

Более взвешенный подход к договорному определению убытков мы находим на следующем этапе развития правоприменительной практики. Знаковым в этой связи является рассмотрение обзора практики Президиумом ВАС РФ, результаты которого были изложены последним в информационном письме № 156 от 26 февраля 2013 года. В нем высшая судебная инстанция сделала сразу несколько важных выводов относительно возможности применения конструкции $30 У$ в отечественной практике:

Во-первых, Президиум признал факт «отсутствия полного аналога данного института в законодательстве РФ», сняв вопрос отождествления $30 У$ с неустойкой.

Во-вторых, Высший арбитражный суд РФ установил общее соответствие ЗОУ основам отечественного правопорядка, в этой связи разрешив дискуссию о компенсационной природе их возмещения как меры гражданско-правовой ответственности.

В-третьих, высшая судебная инстанция определила критерий действительности условий о 3ОУ: последние должны представлять результат разумной оценки предвидимых убытков, выполненной сторонами в отсутствие признаков злоупотребления свободой договора.

И, наконец, в-четвертых, как компенсационной мере гражданско-правовой ответственности ЗОУ должна быть чужда штрафная составляющая, поэтому судам при разрешении дел о возмещении ЗОУ необходимо в каждом случае «оценивать, насколько значительным является карательный характер ответственности должника», при этом, как замечает Президиум, «один лишь факт превышения заранее согласованными сторонами в договоре убытками суммы фактически понесенного компанией реального ущерба или упущенной выгоды не может свидетельствовать об их карательном характере».

Стоит отметить, что такая правовая позиция в полной мере соответствует подходу, сложившемуся в судебной практике стран общего права (см., например, дела Rex Trailer Co., Inc. v. US; Riebe \& Sons., Inc. v. US; US v.
JD Streett \& Co; US v. Le Roy Dyal Co.) и в практике МКАС (см., например, Решение МКАС при ТПП РФ от 28 мая 1999 г. по делу № 243/1998). Кроме этого, по мнению суда, возмещение $30 У$ без установления размеров реального ущерба и упущенной выгоды не влечет неосновательного обогащения кредитора и наказания должника как нарушителя договорных условий.

Согласно общему подходу, выработанному в данном обзоре судебной практики, ЗОУ носят штрафной характер лишь в случае многократного превышения их суммы не над размерами действительно понесенных убытков, а над убытками, которые «стороны могли разумно предвидеть при заключении договора».

Таким образом, на данном этапе развития правоприменительной практики прослеживается корректное восприятие конструкции ЗОУ и признается возможность ее использования в отечественной практике.

\section{Третий этап: правомерность договорного порядка определения убытков}

Следующим этапом развития отечественной правоприменительной практики явилось восприятие идеи договорного порядка определения убытков, признания соответствующих условий договора правомерными и в полной мере отвечающими законодательству РФ в силу действия принципа свободы договора, а также положений ст. 309 ГК РФ. Так, например, Президиум ВАС РФ в Постановлении от 18 июня 2013 г. № 18081/12 по делу № А32-17297/2011 отметил следующее:

Во-первых, договор может устанавливать порядок определения размеров убытков его сторон. При этом «надлежащее исполнение обязательств, возникающих из такого соглашения, возложено на его участников ст. 309 ГК РФ и подлежит установлению судами при разрешении возникших споров».

Во-вторых, судам надлежит оценивать действия сторон по определению размера убытков на соответствие договорным условиям, поскольку нарушение последних выступает основанием для возмещения убытков в установленном договором размере. Кроме того, в целях формирования единообразия в 
толковании и применении арбитражными судами норм права суд указал, что назначения экспертизы в случаях договорного определения убытков не требуется.

При этом в указанном случае суд закрепил оговорку о возможности пересмотра дел со схожими фактическими обстоятельствами, принятых на основании нормы права в истолковании, расходящемся с содержащимся в Постановлении толкованием, на основании п. 5 ч. 3 ст. 311 АПК РФ.

\section{Выводы}

Заметим, что принятие указанного ранее информационного письма задало новый вектор развития судебной практики в отношении договорного определения убытков. Суды отныне недвусмысленно указывают, как, например, в Постановлении Восьмого арбитражного апелляционного суда от 26 ноября 2015 г. № 08АП-12937/2015 по делу № A70-6015/2015, что «убытки могут быть заранее оценены и возмещены по соглашению сторон. Какихлибо запретов на этот счет гражданское законодательство не содержит. Более того, подобного рода договоренности полностью соответствуют принципу свободы договора». При этом данная правовая позиция прочно укоренилась в правоприменительной практике судов (см., например, постановления ФАС Западно-Сибирского округа от 24 июля 2014 г. по делу № А75-616/2013, ФАС Северо-Кавказского округа от 24 июня 2014 г. по делу № А32-3514/2013, Арбитражного суда Московского округа от 4 августа 2016 г. № Ф059592/2016 по делу № А40-196123/15-29-1594, Арбитражного суда Северо-Кавказского округа от 31 октября 2016 г. № Ф08-7602/2016 по делу № А32-37242/2015).

Заметим, что изменение судебной практики возмещения убытков не является редким явлением для российской действительности. В частности, на сегодняшний день в юридической литературе обсуждается вопрос изменения пути развития практики возмещения убытков с лиц, входящих в состав органов юридического лица [1; 2, с. 121].

Возвращаясь к изложенному, отметим, что динамика развития рассматриваемой судебной практики свидетельствует о смене традиционных представлений о механизме определения убытков, усилении частноправовых начал в указанной сфере, а также определяет тенденцию к сближению правового регулирования возмещения убытков с правопорядками ряда стран континентальной Европы, а также стран общего права.

Изначально отрицая возможность договорного определения убытков и отождествляя рассматриваемый вид убытков с неустойкой, судебная практика впоследствии воспроизводит общую идею ЗОУ. При этом смена представлений о возможности договорного определения убытков не была вызвана изменениями законодательства - соответствующие нормы о свободе договора и незыблемости его условий для сторон имелись с момента принятия ГК РФ. Однако мы полагаем, что общий вектор развития договорной ответственности во многом задан именно реформированием гражданского законодательства, в ходе которого последнее вобрало в себя институты, широко применяемые в первую очередь в странах общего права, где принцип свободы договора зачастую ставится выше принципа справедливости, реализация которого, как правило, возложена на суд.

\section{СПИСОК ЛИТЕРАТУРЫ}

1. Долинская, В. В. Общая характеристика и правосубъектность юридических лиц: новеллы гражданского законодательства / В. В. Долинская // Вестник Волгоградского университета. Серия 5, Юриспруденция. - 2015. - № 2. - С. 46-52.

2. Иншакова, А. О. Новая политика ответственности единоличного исполнительного органа хозяйственного общества при совершении невыгодной сделки / А. О. Иншакова, И. А. Турбина // Вестник Пермского университета. Серия «Юридические науки». - 2014. - № 4. - С. 119-127.

3. Крашенинников, М. П. Меры гражданскоправовой ответственности за неисполнение обязательств : автореф. дис. ... канд. юрид. наук / Крашенинников Михаил Павлович. - Саратов, 2012. - 28 с.

\section{REFERENCES}

1. Dolinskaya V.V. Obshchaya kharakteristika i pravosubyektnost yuridicheskikh lits: novelly grazhdanskogo zakonodatelstva [General Characteristics and Legal Personality of Legal Entities: Innovations of 


\section{ВОПРОСЫ ЧАСТНОПРАВОВОГО РЕГУЛИРОВАНИЯ}

Civil Legislation]. Vestnik Volgogradskogo gosudarstvennogo universiteta. Seriya 5, Yurisprudentsiya [Science Journal of Volgograd State University. Jurisprudence], 2015, no. 2, pp. 46-52.

2. Inshakova A.O., Turbina I.A. Novaya politika otvetstvennosti edinolichnogo ispolnitelnogo organa khozyaystvennogo obshchestva pri sovershenii nevygodnoy sdelki [The New Policy of Responsibility of the Sole Executive Body of the Economic Society in the Commission of a Bad Bargain]. Vestnik Permskogo universiteta. Yuridicheskie nauki, 2014, no. 4, pp. 119-127.

3. Krasheninnikov M.P. Mery grazhdanskopravovoy otvetstvennosti za neispolnenie obyazatelstv: avtoref. dis. ... kand. yurid. nauk [Measures of Civil Legal Liability for Failure to Fulfill Obligations. Cand. jurid. sci. abs. diss.]. Saratov, 2012.28 p.

\section{Information about the Author}

Alexander V. Syatchikhin, Master of Jurisprudence, Doctoral Student, Department of Entrepreneurial Law, Civil and Arbitration Procedure, Perm State National Research University, Bukireva St., 15, 614990 Perm, Russian Federation, saw065@mail.ru.

\section{Информация об авторе}

Александр Валентинович Сятчихин, магистр юриспруденции, аспирант кафедры предпринимательского права, гражданского и арбитражного процесса, Пермский государственный национальный исследовательский университет, ул. Букирева, 15, 614990 г. Пермь, Российская Федерация, saw065@mail.ru. 